\title{
The Application of Flipped Classroom in Colleges and Universities Piano Collective Classes
}

\author{
Hui Wang \\ Zhaoqing College, Zhaoqing, China \\ Email: wanghui@163.com
}

How to cite this paper: Wang, H. (2018). The Application of Flipped Classroom in Colleges and Universities Piano Collective Classes. Creative Education, 9, 1021-1026. https://doi.org/10.4236/ce.2018.97075

Received: April 2, 2018

Accepted: June 3, 2018

Published: June 6, 2018

Copyright $\odot 2018$ by author and Scientific Research Publishing Inc. This work is licensed under the Creative Commons Attribution International License (CC BY 4.0).

http://creativecommons.org/licenses/by/4.0/

\begin{abstract}
The teaching concept of "flipped classroom" has gained wide attention in the field of education in recent years. At present, the researches in music class focus on music theory, and there is few in piano collective teaching. Nowadays, most of the music courses teaching (except piano, vocal music) is the same as other subjects. The traditional teaching mode of "teachers teach knowledge in class and students complete homework after class" has been used. The biggest problem of this traditional music education model is that students have poor learning initiative, the teaching process is rigid and teaching effect is poor. The flipped classroom encourages students to study by themselves before class and complete the task list according to the teacher's guidance. In addition, there are many students in the major courses of professional theory, and it is too difficult for teachers to make corresponding teaching arrangements for each student's situation. For which, teachers can only take care of the students of moderate degree in the class that constitute the majority of the class. For those students who learn fast and slow, it is often difficult to take care of them. As a result, the teaching effect is not satisfactory. With the wide application of electronic technology in colleges or universities classrooms, the teaching mode of "flipped classroom" is gradually cultivated. It has received extensive attention from education field both at home and abroad. This article analyzes the present situation of piano collective teaching in colleges and universities, the science and superiority of flipped classroom, and problems and obstacles that could possibly occur, then puts forward some measures to use the "flipped classroom" method.
\end{abstract}

\section{Keywords}

Flipped Classroom, Music, Piano, Collective Teaching 


\section{Introduction}

The "Flipped classroom" is "Flipped Class Model", also named "reverse class". It originated in the "woodland park" high school in the Rocky Mountains of Colorado. In flipped classroom, the knowledge transfer stage is completed by students independently and collaboratively before class. And the knowledge internalization stage is arranged by teachers according to different teaching design strategies in class. Personalized learning respects individual differences, and meets the learning needs of personality such as learning strategy, resources, etc. It has become one of the development trends of education (Zhong, Song, \& Jiao, 2013).

By using the convenience of network information technology, the flipped classroom breaks the traditional teaching process, and encourages teachers to make a short teaching video before class, share and transfer other learning materials and tasks to students via network platform in order to let the students study by themselves and complete the task list according to the teacher's guidance. And teachers can master the students' learning situation through the students' learning information from the network platform, then they can focus on the teaching content in class, work with the students together to solve the problems and finish homework at last. At present, the application of flipped classroom in music classroom is gradually involved in music disciplines such as music theory, harmony, song allocation and vocal music. It is of great significance to study and explore the "flipped classroom" mode in piano collective lessons at this time.

\section{The Current Situation of Piano Collective Teaching in Colleges and Universities}

The collective piano class is a public skill course offered by teachers of colleges and universities for pre-school education and primary school education. It is a comprehensive course that combines music theory with music appreciation with piano playing as the main line. After many years of development, piano collective teaching has obvious advantages. It reduces the cost of teaching and improves the efficiency of teaching. However, due to the reasons of class hour, venue, large number of students and many teaching contents, the limitations of piano collective class are becoming more and more prominent. In actual piano collective teaching, piano playing occupies the most of the time of classroom teaching. Music theory and music appreciation teaching are difficult to carry out. And it is also very difficult to carry out systematic music theory study. This is contrary to the goals of comprehensively improving students' music literacy and training comprehensive talents. Therefore, the teacher begins to explore the new mode of piano collective teaching (Zhang, Wang, \& Zhang, 2012).

\section{The Science and Superiority of Flipped Classroom}

"Flipped classroom" has its own scientificity and superiority. For example, it can effectively cultivate students' autonomous learning ability. In the traditional piano 
class, for most of the time, the teachers lead the students to read the new music, take practice, and explain the movement essentials. Most students are passive learners. Even some students who had been learning two years of piano lessons lack the ability to read music. In the flipped classroom, students can receive the homework assigned by teachers before class in advance and can independently complete the task list set by the teachers. As a result, they become able to identify problems in practice and try to solve them. The flipped classroom will give students more initiatives. The following is the practical analysis of "flipped classroom" in piano collective lessons.

\section{1. "Flipped Classroom" Makes Pre-Class Preparation More Targeted}

Through teaching practice, it can be found that "flipped classroom" teaching mode can make teaching more targeted. It can make classroom teaching efficiency and quality higher. Take the song of If You Are Happy as an example, through pre-class preparation, students think that the continuous rhythm of the music is more difficult to master. As to the difficulties of students, teachers could prepare a variety of teaching programs when preparing the class. They could solve the contiguous problems by means of reading pronunciations, also they could let the students listen and imitate the singing with the continuous rhythm of the song in order to achieve the purpose of becoming familiar with the rhythm.

Through the "flipped classroom" pre-class preparation, students' learning of the knowledge has changed from the process of class, after class into the process of before class, class (multiple methods), and after class. Teachers will check simultaneous tasks on the same day of the class. This change can effectively deepen students' learning impression and improve teaching quality.

\subsection{Flipped Classroom Makes Teaching Interaction More Active}

In flipped classroom, class time is saved due to pre-class preview and targeted explanation. Teachers can carry out a variety of teaching activities, such as double ensemble, group ensemble, musical instrument ensemble, playing and singing combination, song matching, melody creation, etc. Rich and varied teaching activities make higher demands on students and teachers, also make piano class become more lively and vivid. For example, in teaching the song of If You Are Happy, after basically solving the difficulty of playing, teachers could ask students to dance or sing on the basis of music playing. Teachers can also encourage students to try adapting music, lyrics, etc. in order to stimulate students' interest in learning, so that students have a more comprehensive understanding of music. At the same time, cultivate students' creativity and make piano teaching more practical (Jacob, 2013).

\subsection{Flipped Classroom Makes the After-School Evaluation System More Reasonable}

Teaching evaluation is very important in flipped classroom. In the traditional 
class teaching of piano group, students' playing is the most important evaluation standards. This single evaluation system which attaches importance to results is not conducive to the development of students' music quality. For students, mastering music basic theory knowledge, having music appreciation and music comment abilities are also crucial. The evaluation system of "flipped classroom" includes the completion of "learning task list" before class, the euphoric group cooperation, self-selection track, melody creation presentation, and class review video, etc. This kind of process learning evaluation can stimulate students' creativity and imagination. To sum up, it is of practical significance to study the application of "flipped classroom" in piano collective lessons. It can effectively improve the efficiency of piano classroom teaching and stimulate students' interest in piano learning, encourage students to learn the piano by themselves and improve their practical ability, solve the common problems of students' failure in class and not knowing how to practice after class effectively (Guo, Gao, \& Ning, 2014).

\section{Applying the Teaching Mode of "Flipped Classroom" to Music Classes in Colleges and Universities Will Have a Good Effect on Improving Teaching Effect}

This paper puts forward some ways of how to use the "flipped classroom" mode in music teaching from the following aspects:

\subsection{Design before Class}

Pre-class design is mainly the production of class videos and the arrangement of pre-class thinking. The production of "Flipped classroom" music teaching video should be recorded by teachers of each course. Teachers should set the teaching content, teaching objectives, teaching process and teaching time according to the students' basis and receiving ability. At the same time, teachers can make a targeted explanation of the teaching contents according to the actual situation of students. For example, when explaining the notes and the rest, the teachers can add some vivid pictures or animations in video to deepen the students' understanding, then emphasize on the difficult knowledge points. In addition, teachers should also consider visual effects, theme points, curriculum structure and the time that students' are able to watch video when making videos. At the same time, in order to enable students to concentrate on learning video before class, the main contents of video course can be made into handouts to students in advance, so that students don't have to be busy in copying their notes and influence the listening of lectures. After the before class learning, students should complete the pre-class exercises, inform the teachers of the problems encountered in the study in time, and communicate and discuss with the students through QQ, message board and other online communication tools (Zhao, Xu, \& Liu, 2014).

\subsection{Classroom Activities Design}

The classroom activity of "flipped classroom" is completely different from tradi- 
tional classroom teaching. Teachers should make a list of some representative questions for students to discuss in class according to the questions raised by video and practice before class. Students can choose the topics that they are interested in to discuss in class. Then divide the class into a number of discussion groups according to the selected topics. Each team shall control the team members within 10 persons. If there are too many people in a team, the team could be subdivided into smaller groups for discussion. Finally, teachers gather students together for collaborative research. Such an individualized classroom learning environment can encourage students to learn independently, make good use of technical tools for pre-class learning, and under the guidance of teachers in the classroom to carry out active discussion and exploration. The teaching micro videos is demonstration video of music theory and playing made by teachers before class. Music theory video focuses on strong pertinence, and the explanation of knowledge points should be concise and easy to understand. The duration time should be limited within 3 to 8 minutes. While it is necessary to extract the more difficult knowledge points in the play to record separately when recording the playing demo video. By this way, teachers could guide students to understand the difficult points. Network platform teaching has the advantage of free time and space limitation, students can learn according to their own needs (Zheng, 2014).

\subsection{After-Class Feedback Evaluation}

At the end of the course, both teachers and students should put their feelings and experiences on the course platform. Everyone should make a positive evaluation of their learning process. Real quantitative and qualitative evaluation, formative assessment and summative evaluation, individual evaluation and evaluation of the group, self-evaluation and other evaluation should be combined.

\section{Frictions That "Flipped Classroom" May Encounter}

As a teaching method, the "flipped classroom" will have a far-reaching impact on education career in the future. But at the beginning of application, there will be a lot of friction with the traditional teaching mode, which brings the education workers some problems and obstacles. For example, at "Flipped classroom" pre-class learning stage, without the strict requirements and supervision of teachers in the classroom, some students will not consciously learn. So teachers should communicate with students in private and urge students to study independently, then let the students develop the habit of active learning gradually. Besides, the producing the before class video has new and high requirements for every teacher. Therefore, colleges and universities should strengthen the training of teachers' information technology application ability (Felder \& Silverman, 1988).

\section{Conclusion}

Building a teaching network platform is a prerequisite for implementing flipped 
classroom in the information age. Teachers can make full use of the network platform to publish teaching micro video, develop learning task list, and guide students to conduct correct and active learning. Under the network teaching mode, students should preview and practice the new course content through the network teaching platform provided by the teacher before class.

In the classroom, teachers and students collaboratively explore and study the difficulties and finish the homework. This new teaching mode enables personalized education, promotes piano collective lessons to update the teaching ideas and keep pace with the Times.

The innovative flipped classroom reversed the organizational structure of the traditional classroom and emphasized the cultivation of individual independence and cooperative learning ability. Personalized learning respects the difference of individual cognition level and learning style, and can meet the learning needs of personality (including learning strategies, resources, etc.). The integration of personalized learning concept and flipped classroom can reflect the characteristics of students centered in flipped classroom. It is helpful to improve learners' enthusiasm and support the implementation of flipped classroom. At present, the flipped classroom teaching model based on personalized learning concept is still facing challenges in practice. It is necessary for the researcher to explore and perfect new teaching methods in order to provide reference for teaching quality reform.

\section{References}

Felder, R. M., \& Silverman, L. K. (1988). Learning and Teaching Styles in Engineering Education. Engineering Education, No. 7, 674-681.

Guo, J., Gao, D. H., \& Ning, Y. W. (2014). Design of Flipped Classroom Based on Canvas LMS-Take the "Education Technology" Course of Northwestern University as An Example. Modern Educational Technology, No. 12, 118-123.

Jacob, E. (2013). Looking at the Impact of the Flipped Classroom Model of Instruction on Undergraduate Multimedia Students at CSUN. Tech Trends: Linking Research \& Practice to Improve Learning, No. 6, 14-27.

Zhang, J. L., Wang, Y., \& Zhang, B. (2012). Study on Flipped Classroom Teaching Mode. Journal of Distance Education, No. 4, 46-51.

Zhao, C. L., Xu, J. J., \& Liu, Q. T. (2014) Design and Application of Flipped Classroom Teaching Mode Based on Micro Video Resources. Modern Educational Technology, No. 12, 70-76.

Zheng, Y. X. (2014) The Study of Individualized Learning in Information Technology Environment. China Educational Technology, No. 7, 126-132.

Zhong, X. L., Song, S. Q., \& Jiao, L. Z. (2013) Research on Teaching Design Based on Flipped Classroom Concept in Information Environment. Open Education Research, No. 1, 58-64. 